\title{
Fracture resistance of occlusal veneer and overlay CAD/CAM restorations made of polymer-infiltrated ceramic and lithium disilicate ceramic blocks
}

\author{
Polimer-infiltre seramik ve lityum disilikat seramikten üretilen okluzal vener \\ ve overlay CAD/CAM restorasyonların kırılma dayanımlarının incelenmesi
}

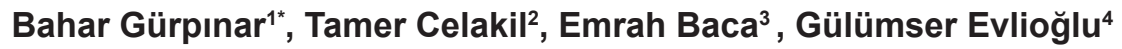 \\ 1 İstanbul Okan Üniversitesi Dişhekimliği Fakültesi, Protetik Diş Tedavisi Anabilim Dalı, İstanbul, Türkiye, Orcid': 0000-0002-3884-2073 \\ 2 İstanbul Üniversitesi Dişhekimliği Fakültesi, Protetik Diş Tedavisi Anabiliim Dalı, İstanbul, Türkiye, Orcid²: 0000-0002-8085-6356 \\ 3 İstanbul Üniversitesi Dişhekimliği Fakültesi, Protetik Diş Tedavisi Anabiliim Dalı, İstanbul, Türkiye, Orcid³: 0000-0003-2688-8338 \\ ${ }^{4}$ İstanbul Üniversitesi Dişhekimliği Fakültesi, Protetik Diş Tedavisi Anabiliim Dalı, İstanbul, Türkiye, Orcid²: 0000-0003-4688-8204
}

Atıf/Citation: Gürpınar, B., Celakil, T., Baca, E. \& Evlioğlu, G. (2020). Fracture Resistance of Occlusal Veneer and Overlay CAD/ CAM Restorations Made of Polymer-Infiltrated Ceramic and Lithium Disilicate Ceramic Blocks. Ege Üniversitesi Diş Hekimliği Fakültesi Dergisi, 41(2), 131-142.

\begin{abstract}
Introduction: Purpose of this study was to evaluate the fracture resistance of occlusal veneer and overlay CAD/CAM restorations made of polymer-infiltrated ceramic and lithium disilicate ceramic.

Methods: 60 non-carious mandibular first molar teeth were divided into 5 groups: Polymer-infiltrated ceramic (PIC)-overlay group (n: 12), PIC-occlusal veneer group (n: 12), Lithium disilicate ceramic (LDC)-overlay group (n: 12), LDC-occlusal veneer group ( : 12) and control group ( $n: 12)$ which was consisted of natural teeth. Standard overlay and occlusal veneer cavities were prepared. Restorations were manufactured using CEREC, cemented with adhesive resin cement. All specimens subjected to artificial aging process in mastication simulator, fracture resistance was assessed with universal testing machine. Fractured surfaces were examined with stereomicroscope.
\end{abstract}

Results: Obtained data were evaluated with 1-way ANOVA, Tukey HSD and Student $t$ tests. In terms of fracture force values, no

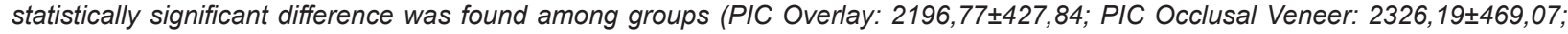
LDC Overlay: 1960,16 $\pm 438,85$; LDC Occlusal Veneer: $2148,53 \pm 460,18)$ except control group $(2942,3 \pm 724,60)$. In terms of failure modes, no statistically significant difference was found among groups; occlusal veneer restorations showed mostly Burke class I-II fractures.

Discussion and Conclusion: For restorative treatment of posterior worn teeth, minimal invasive occlusal veneer restorations made of $L D C$ or PIC materials are successful alternatives.

Keywords: polymer-infiltrated ceramic, lithium-disilicate ceramic, fracture resistance, occlusal veneer, overlay, CAD/CAM, tooth wear

\section{ÖZ}

Giriş ve Amaç: Çalışmanın amacı; polimer-infiltre seramik ve lityum disilikat seramikten üretilen okluzal vener ve overlay CAD/ CAM restorasyonları kırılma direnci açısından kıyaslamaktır.

Yöntem ve Gereçler: 60 adet çürüksüz büyük azı dişi 5 gruba ayrılmıştır: Polimer-infiltre seramik (PIC)-overlay (n: 12), PICocclusal Veneer (n: 12), Lityum disilikatla güçlendirilmiş seramik (LDC)-overlay ( $n: 12)$, LDC occlusal veneer ( $n: 12)$ ve doğal dişlerden oluşan kontrol grubu (n: 12). Standart overlay ve okluzal vener preparasyonları hazırlanmıştır. Restorasyonlar CEREC ile üretilmiş, adeziv rezin siman ile simante edilmiştir. Tüm örneklere çiğneme simülatörü cihazı yardımıyla yapay yaşlandırma işlemi uygulanmış, üniversal test cihazı ile kırılma kuvvetleri belirlenmiştir. Kırık yüzeyler stereomikroskop yardımıyla incelenmiştir.

Bulgular: Veriler Tek-Yönlü Anova, Tukey HSD test ve Student t testi kullanılarak değerlendirilmiştir. Kırılma kuvveti açısından kontrol

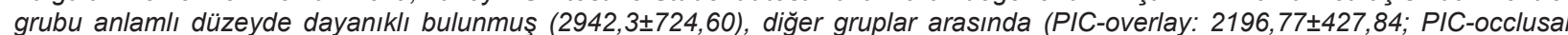
veneer: 2326,19 $\pm 469,07$; LDC overlay: 1960,16 $\pm 438,85$; LDC occlusal veneer: $2148,53 \pm 460,18)$ anlamlı farklılık tespit edilmemiştir. Kırılma paterni açısından gruplar arasında anlamlı farklıık tespit edilmemiş; okluzal vener restorasyonlarda daha yüksek oranda Burke sınıf I-Il kırıklar görülmüştür.

Tartışma ve Sonuç: LDC ve PIC materyallerinden üretilen minimal invaziv okluzal vener restorasyonların, posterior bölge dental aşınma olgularının restorasyonunda başarılı bir tedavi alternatifi olduğu saptanmıştır.

Anahtar Kelimeler: polimer-infiltre seramik, lityum disilikat seramik, kırılma dayanımı, okluzal vener, overlay, CAD/CAM, diş aşınması

Sorumlu yazar/Corresponding author*: bahargurpinar@gmail.com

Başvuru Tarihi/Received Date: 05.12.2019

Kabul Tarihi/Accepted Date: 03.03.2020 


\section{INTRODUCTION}

Occlusal enamel may be severely worn for various reasons, exposing underlying dentin and even the pulp. ${ }^{1}$ The etiology can be a mechanical (attrition, abrasion and abfraction) and/or chemical (erosion) mechanism., ${ }^{2,34}$ The wear may cause pulpal complications, loss of vertical dimension, masticatory dysfunction and pain, temporomandibular disorders and psychological problems. ${ }^{3,4}$ Tooth eruption may compensate for lost tooth structure, leading to lack of restorative space. Therefore, restorative treatment of severely worn teeth may require invasive and expensive treatment procedures; including endodontic treatment, crown lengthening and complete crown restorations. Current guidelines attach importance to developing minimally invasive treatment methods by reducing the removal of tooth tissue and treatment time. ${ }^{2,5}$

Minimally invasive procedures, direct composite resins, indirect ceramic or composite resin restorations or a combination have helped to prevent excessive tooth substance loss, maintained tooth vitality, and reduced treatment time. A contemporary approach for the treatment of tooth wear is minimal tooth preparation with ultrathin restorations (a few tenths of a millimeter). These ultrathin occlusal veneers are a conservative alternative to conventional overlay or complete crown restorations $s^{1,3,6}$ The tooth preparation for occlusal veneers is straightforward as the anatomic structure of the teeth is maintained and the interocclusal distance is taken into consideration. They have a minimal thickness of 0.4 $\mathrm{mm}$ to $0.6 \mathrm{~mm}$ at the developmental grooves and 1.0 $\mathrm{mm}$ to $1.3 \mathrm{~mm}$ at the cusp tips. For many patients, no tooth preparation is needed. Other important advantages of occlusal veneers include the ease of determining the result of an altered vertical dimension with interim restorations and a straightforward cementation process. Moreover, they are similar to anterior porcelain laminate veneers, and the same principles can be applied to both of these restorations. ${ }^{3,7}$

The development of computer-aided design and computer-aided manufacturing (CAD-CAM) technology has introduced many material options for fabricating restorations, but currently, a consensus on the best technique (direct or indirect) or material for the restoration of severely worn teeth is lacking., ${ }^{2,48}$ Lithium disilicate ceramic (LDC) has lithium disilicate crystals embedded in a glassy matrix and is one of the strongest glass-ceramics. LDC has been recommended for use in anterior or posterior veneers, inlays, onlays, crowns, partial coverage restorations and 3-unit fixed dental prostheses. ${ }^{5,9,10,11,12}$ A recently developed CADCAM polymer-infiltrated ceramic network material
(PIC) (hybrid ceramic) may be a suitable option for thin indirect restorations. This material has a reinforcing polymer mesh infiltrated into a dominant ceramic mesh. This ceramic-polymer mesh may provide a material that combines the positive properties of ceramics and resins ${ }^{10}$ and be suitable for thin posterior restorations because of high resistance to masticatory loads. According to the manufacturer, it absorbs and distributes chewing forces well and is indicated for posterior restorations. However, the mechanical behavior of PIC should be investigated when it used for fabricating ultrathin occlusal veneer restorations. . $^{1,5,8,8,13}$

Studies on the performance of LDC and PIC materials when used for posterior ultrathin restorations are lacking. Moreover, occlusal veneers are recently introduced restorations for worn posterior teeth that require in vitro and long-term in vivo studies. Thus, the objective of this study was to compare the loadbearing capacity of occlusal veneers and overlays made of LDC and PIC and to evaluate their fracture resistance when bonded to natural teeth under clinically relevant conditions.

The null hypotheses were that no differences in fracture resistance would be found according to restoration types, that the use of different CAD-CAM materials would have no effect on the fracture resistance of the restorations, and that the restored tooth would have similar fracture resistance to an unrestored tooth.

\section{MATERIALS AND METHODS}

\section{Sample collection and preparation}

Sixty human mandibular third molar teeth were collected at the Istanbul University, Faculty of Dentistry and Department of Oral Surgery. A written consent was signed by all patients whose extracted tooth was used in the current study. Teeth without cavities or restorations, without damage during extraction and of similar size, were selected. Soft tissue on the crown and roots was removed with a periodontal scaler and the teeth were kept in $0.5 \%$ Chloramine-T solution at $4{ }^{\circ} \mathrm{C}$ for less than a month. They were then kept in distilled water until the end of the study. Autopolymerizing pink acrylic resin (Simplex ACR313, Kemdent Ltd., Swindon, UK) was poured into semicircular silicone molds to make bases for attachment to the chewing simulator machine. The teeth were embedded in acrylic resin until $2 \mathrm{~mm}$ below the enamel-cement junction. The mesiodistal, buccolingual and occlusogingival sizes of the teeth were measured, and the teeth of similar size were placed in the same group. A total of 5 groups were formed containing 12 teeth in each (Figure 1). 


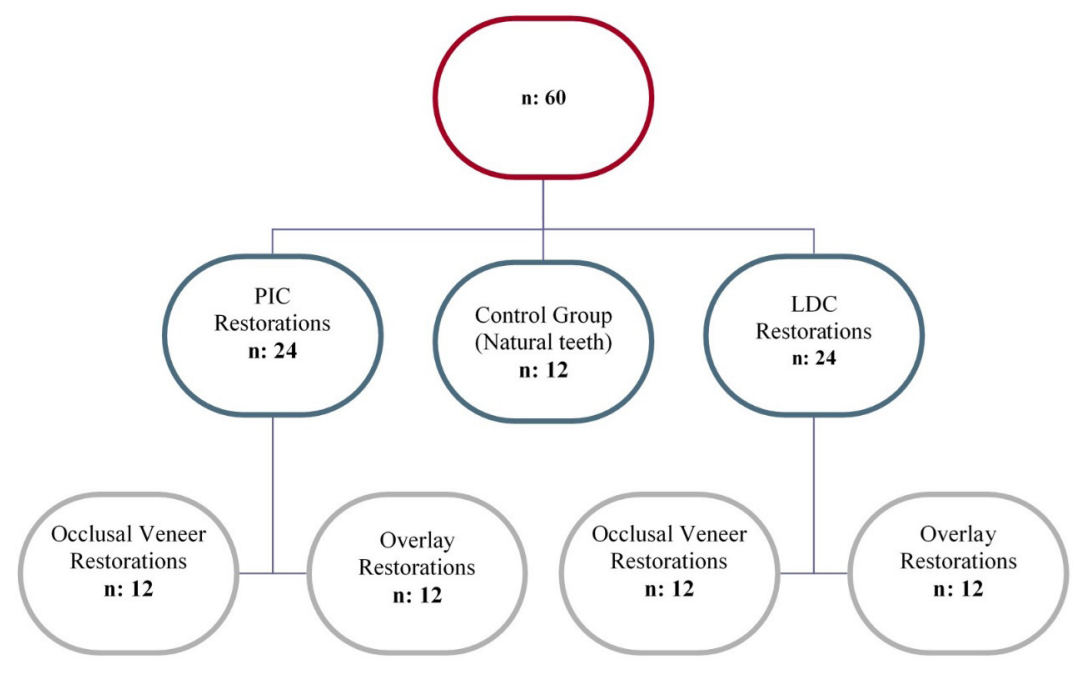

Figure 1: Grouping of specimens

Two different preparation designs were defined for the study groups: overlay preparation group: mesiooccluso-distal box cavity form was applied, and the depth and width of isthmus area was $3 \mathrm{~mm}$. The margins of the mesial and distal box were placed $1 \mathrm{~mm}$ over the enamelcement junction. The width and height of the steps were adjusted to be $2 \mathrm{~mm}$. The functional and nonfunctional cusps were reduced by $2 \mathrm{~mm}$, and the angle between the cavity walls was adjusted to be 6 degrees. Overlay preparations were made with the help of a standard set of rotary instruments (Intensive FG Ser- Inlay Set III Extended, L. Sevük, Prof. Ç. Sevük, İstanbul)

For the occlusal veneer group, a standardized tooth preparation was made to imitate occlusal wear. The worn surface was prepared on the enamel with the help of a standard fissure cutter (Intensive FG-305 L CB) to expose the dentin. Buccal and lingual margins were positioned $5.5 \mathrm{~mm}$ over the enamel-cement junction, and $2.5 \mathrm{~mm}$ over the central fossa, and the cusp curves were protected as much as possible ${ }^{13}$ All cavity preparations were made by a single clinician (B.G.) (Figure 2).

\section{Restoration design and bonding procedure}

A laboratory scanner (CEREC inEos Blue scanner, Dentsply Sirona, Bensheim, Germany) was used to scan the prepared teeth after powdering with CEREC Optispray (Dentsply Sirona, Bensheim, Germany). CEREC 3D inLab software (Dentsply Sirona, Bensheim, Germany) was used for the design of the restorations. For standardization, the occlusal surface of all restorations was adapted from the mandibular first molar tooth anatomy in the CEREC database. For the design of the
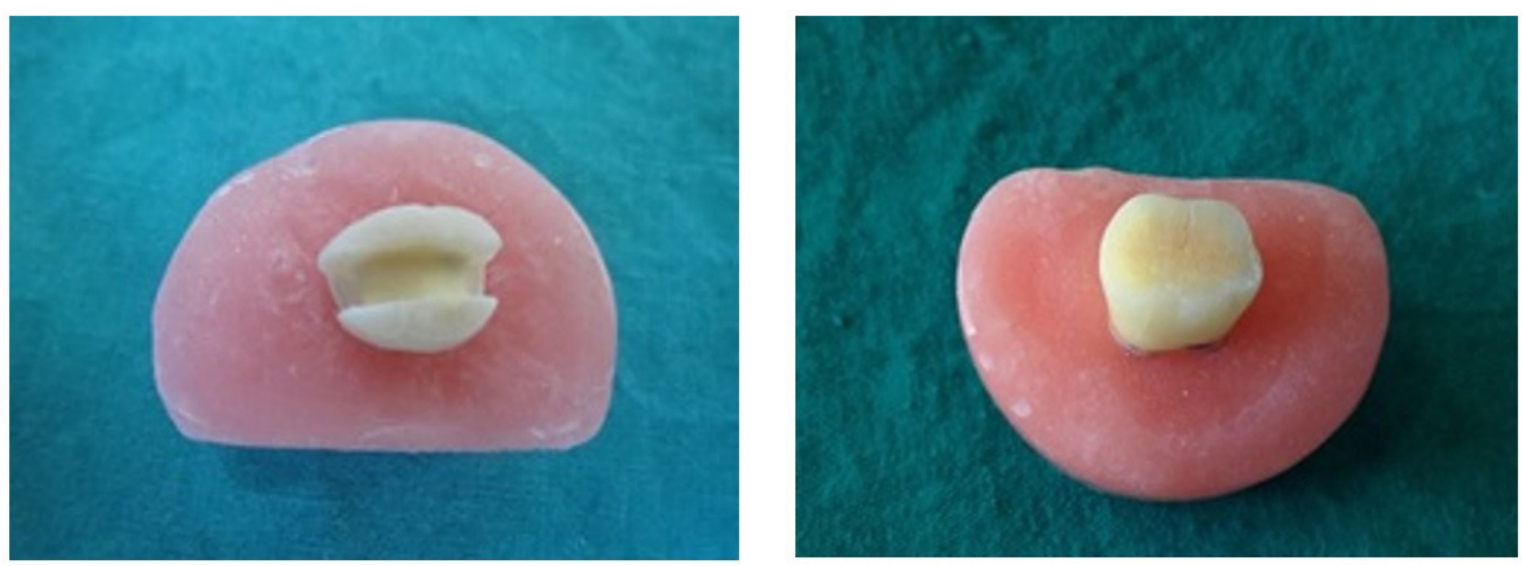

Figure 2: Overlay and occlusal veneer preparations 
occlusal veneer restorations, the occlusal surface was adjusted to be $0.6 \mathrm{~mm}$ deep in the central fossa, $1 \mathrm{~mm}$ between the cusps, and a maximum of $1.3 \mathrm{~mm}$ under the cusp tips by using design tools of the CEREC software. In order to ensure a standardized occlusal surface, the design was performed with positioning tools (including turn and revolve) of the software (Figure 3). The restorations were milled (InLab MC XL, Dentsply Sirona) and data were combined on the computer. Half $(n=24)$ of the restorations were milled from Vita Enamic block (Vita Zahnfabrik, Bad Säckingen, Germany), and the other half $(n=24)$ was milled from IPS e-max CAD (Ivoclar Vivadent AG, Schaan, Liechtenstein). After etching cementation surfaces with hydrofluoric acid gel (Ultradent Porcelain etch, \%9) for $20 \mathrm{~s}$ to standardize the surface conditioning process, all restorations were cemented on the teeth with a dualcure adhesive resin cement (RelyX Ultimate, 3M ESPE, St. Paul, Minnesota), according to the manufacturer's recommendations. Properties of all materials used in the current study were given in Table 1 .

\section{Artificial aging process and fracture test}

The specimens were subjected to a dynamic and thermal fatigue process. For the first artificial aging step, the specimens were subjected to $50 \mathrm{~N}$ force with
$1.6 \mathrm{~Hz}$ frequency ${ }^{3}$ in a moist environment through 100 000 dynamic cycles ${ }^{15}$ in the chewing simulator machine (Chewing Simulator CS-4, SD Mechatronic GmbH, Germany). For a thermal cycling process, the specimens were submerged into two water baths at $5{ }^{\circ} \mathrm{C}$ and $55^{\circ} \mathrm{C}$ for 30 seconds for a total of 5000 cycles ${ }^{5}$ (Figure 4 ). The fracture test was performed by using a universal testing machine (Shimadzu Co., Kyoto, Japan) with loading using a custom 6-mm-diameter spherical stainless-steel tip ${ }^{16,17}$ The tip was placed exactly at the center of the restorations from the buccolingual and mesiodistal sides and touched the restorations on both the buccal and lingual sides (Figure $5)$ to simulate tripod contacts along the cuspal inclines ${ }^{2}$. The crosshead speed was $0.5-\mathrm{mm} / \mathrm{min} .^{2}$ The fracture force value was recorded when cracks or small fractures occurred in the specimens. All specimen fractures were examined with a stereomicroscope (Olympus SZX7) and a camera (Canon EOS 450D) to determine the structures that were included in the fracture, size of the damage and failure mode. The Burke classification ${ }^{18}$ was used to determine the failure mode (Figure 6). Burke classification: I merely the restoration fracture; II the restoration fracture including a small tooth tissue; III the fracture including more than half of the tooth and not including periodontal tissues; IV serious restoration and/or tooth fractures including periodontal tissues (catastrophic fracture).

Table 1: Material properties used in the study

\begin{tabular}{|c|c|c|}
\hline Product & Manufacturer & Composition \\
\hline \multirow{2}{*}{$\begin{array}{l}\text { Polymer Infiltrated } \\
\text { Ceramic Block (PIC) }\end{array}$} & \multirow{2}{*}{$\begin{array}{c}\text { Vita Enamic / } \\
\text { Vita Zahnfabrik / } \\
\text { Bad Sackingen - Germany }\end{array}$} & $\begin{array}{l}\text { Ceramic Component: \% } 58-63 \mathrm{SiO}_{2}, \% 20-23 \mathrm{Al}_{2} \mathrm{O}_{3} \\
\% 6-11 \mathrm{Na}_{2} \mathrm{O}, \% 4-6 \mathrm{~K}_{2} \mathrm{O}, \% 0.5-2 \mathrm{~B}_{2} \mathrm{O}_{3},<\% 1 \mathrm{CaO},<\% 1 \mathrm{TiO}_{2}\end{array}$ \\
\hline & & $\begin{array}{l}\text { Polymer Component : Methyl methacrylate (MMA) free surface modified } \\
\text { polymethylmethacrylate (PMMA) }\end{array}$ \\
\hline $\begin{array}{l}\text { Lithium Disilicate } \\
\text { Ceramic }\end{array}$ & $\begin{array}{l}\text { IPS e.max CAD } \\
\text { Ivoclar vivadent / Schaan - } \\
\text { Liechtenstein }\end{array}$ & $\begin{array}{l}\% 57-80 \mathrm{SiO}_{2}, \% 11-19 \mathrm{Li}_{2} \mathrm{O}, \% 0-13 \mathrm{~K}_{2} \mathrm{O} \\
\% 0-11 \mathrm{P}_{2} \mathrm{O} 5, \% 0-8 \mathrm{ZrO}_{2}, \% 0-8 \mathrm{ZnO} \\
\text { Coloring oxides }\end{array}$ \\
\hline \multirow{2}{*}{ Adhesive Resin Cement } & \multirow{2}{*}{$\begin{array}{l}\text { 3M RelyX Ultimate } \\
\text { 3M ESPE / St. Paul, } \\
\text { Minnesota -USA }\end{array}$} & $\begin{array}{l}\text { Base : Base: Methacrylate Monomers, Radioopaque Fillers, Initiator } \\
\text { Components, Stabilizers, Consistency Adjusters }\end{array}$ \\
\hline & & $\begin{array}{l}\text { Catalyst : Methacrylate Monomers, Radiopaque Alkaline Fillers, Initiator } \\
\text { Components, Stabilizers, Pigments, Consistency Adjusters, Fluorescent Paint, } \\
\text { Chemical Activator for Scotchbond Universal Adhesive }\end{array}$ \\
\hline Bonding Agent & $\begin{array}{l}\text { 3M Scotchbond Universal } \\
\text { Adhesive } \\
\text { 3M ESPE / St. Paul, } \\
\text { Minnesota -USA }\end{array}$ & $\begin{array}{l}\text { MDP Phosphate Monomer, Dimethacrylate Resins, HEMA, Vitrebond } \\
\text { Copolymer, Filler, Ethanol, Water, Initiators, Silane }\end{array}$ \\
\hline Etching Agent & $\begin{array}{l}\text { 3M Universal Acid } \\
\text { 3M ESPE / St. Paul, } \\
\text { Minnesota -USA }\end{array}$ & \%37 Phosphoric Acid \\
\hline Ceramic Etching & $\begin{array}{l}\text { Ultradent Products Inc. / } \\
\text { South Jordan - USA }\end{array}$ & \%9 Hydrofloric Acid \\
\hline
\end{tabular}



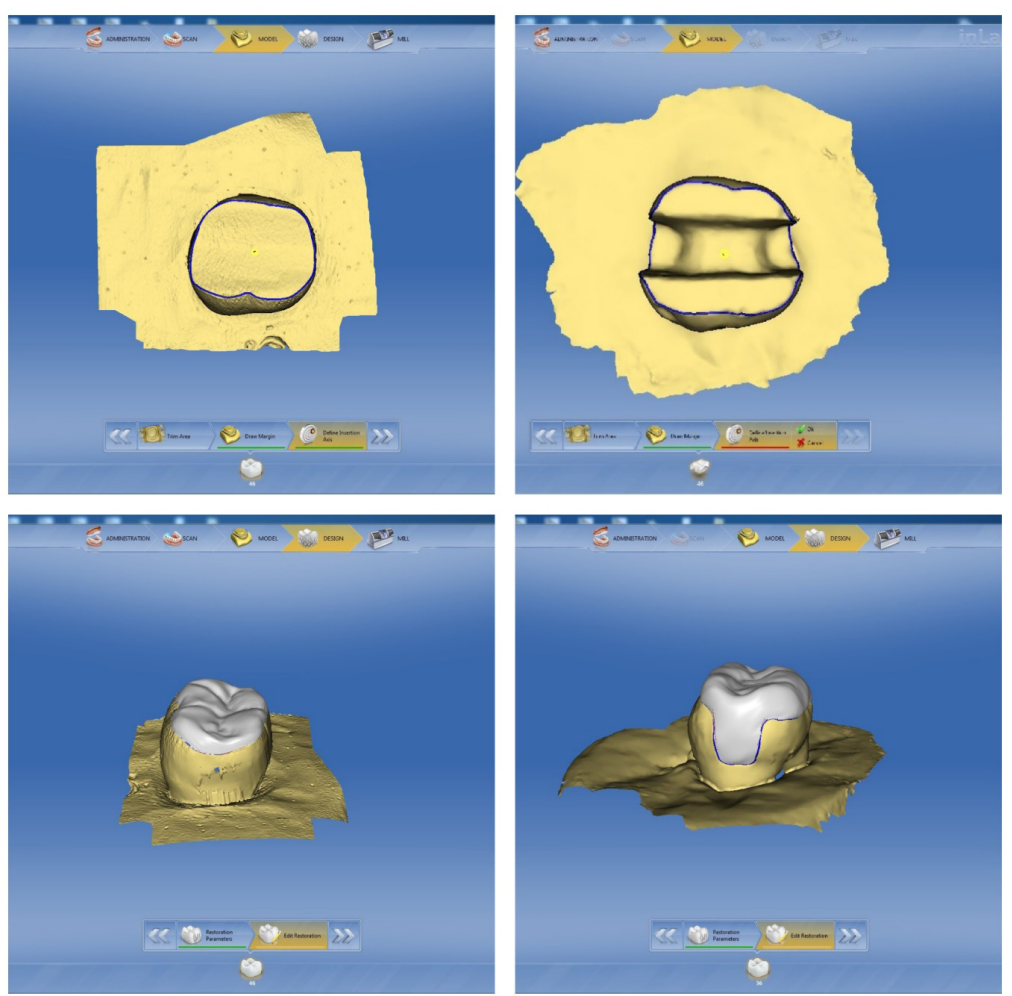

Figure 3: Virtual designs of occlusal veneer and overlay restorations
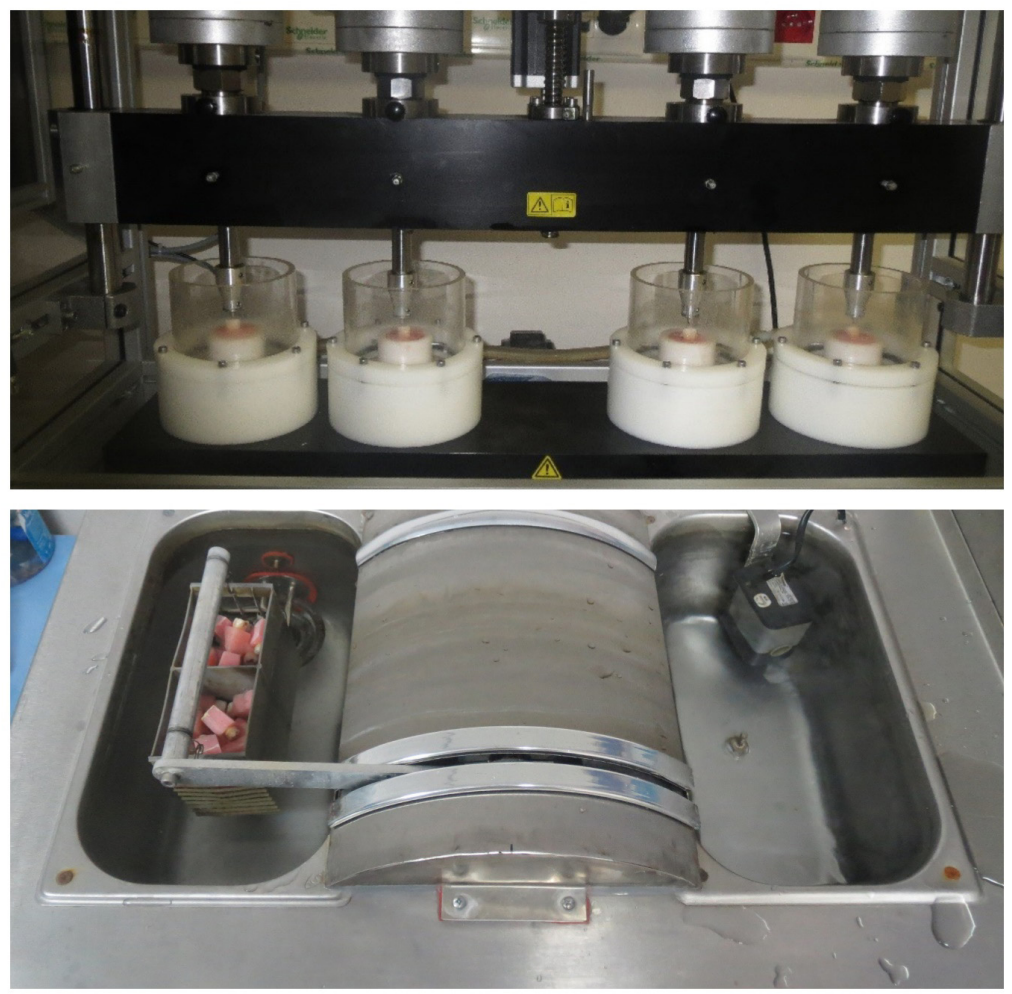

Figure 4: Artifical aging process of the specimens 


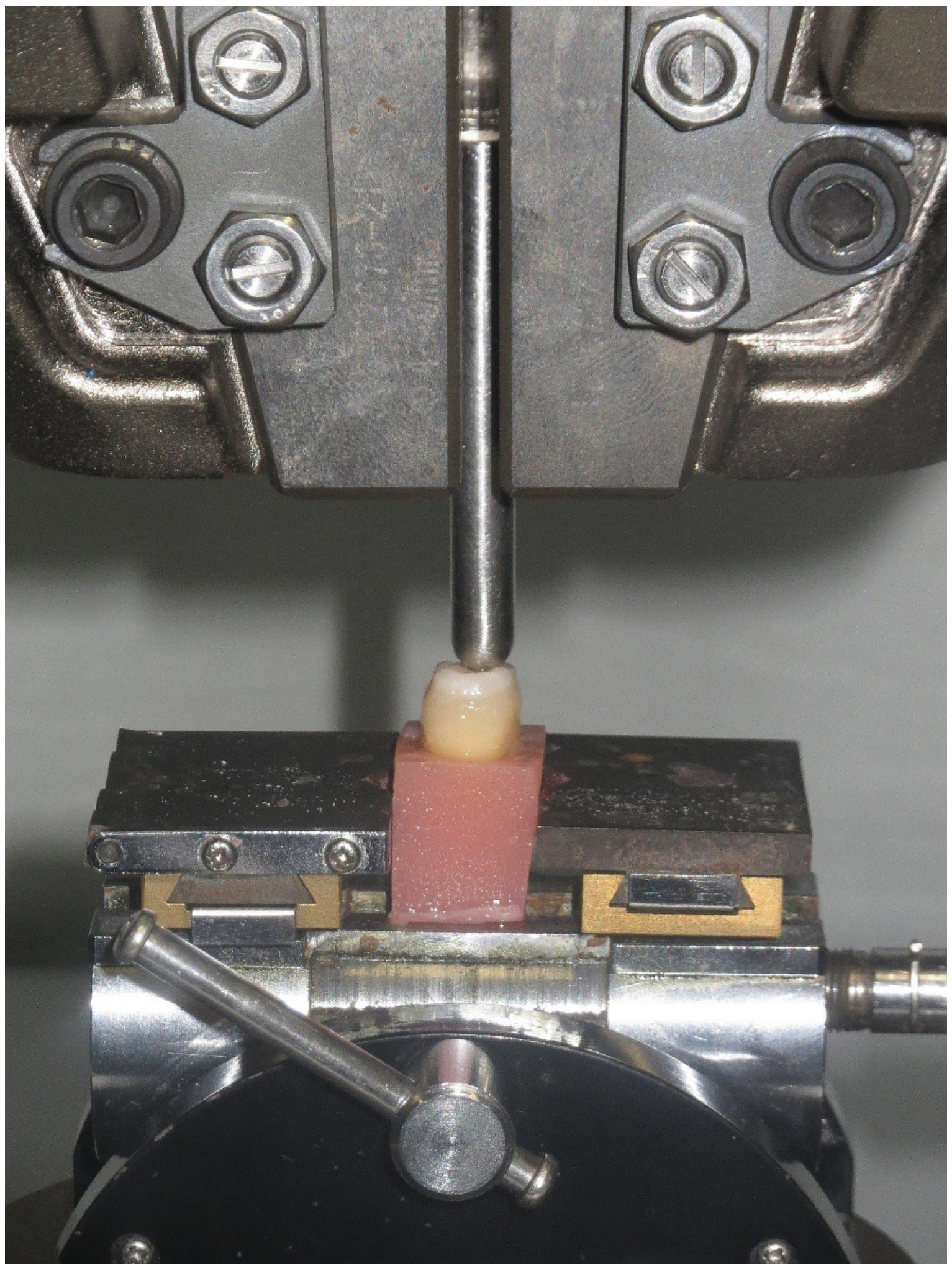

Figure 5: Static loading of specimens for fracture test in the universal testing machine 

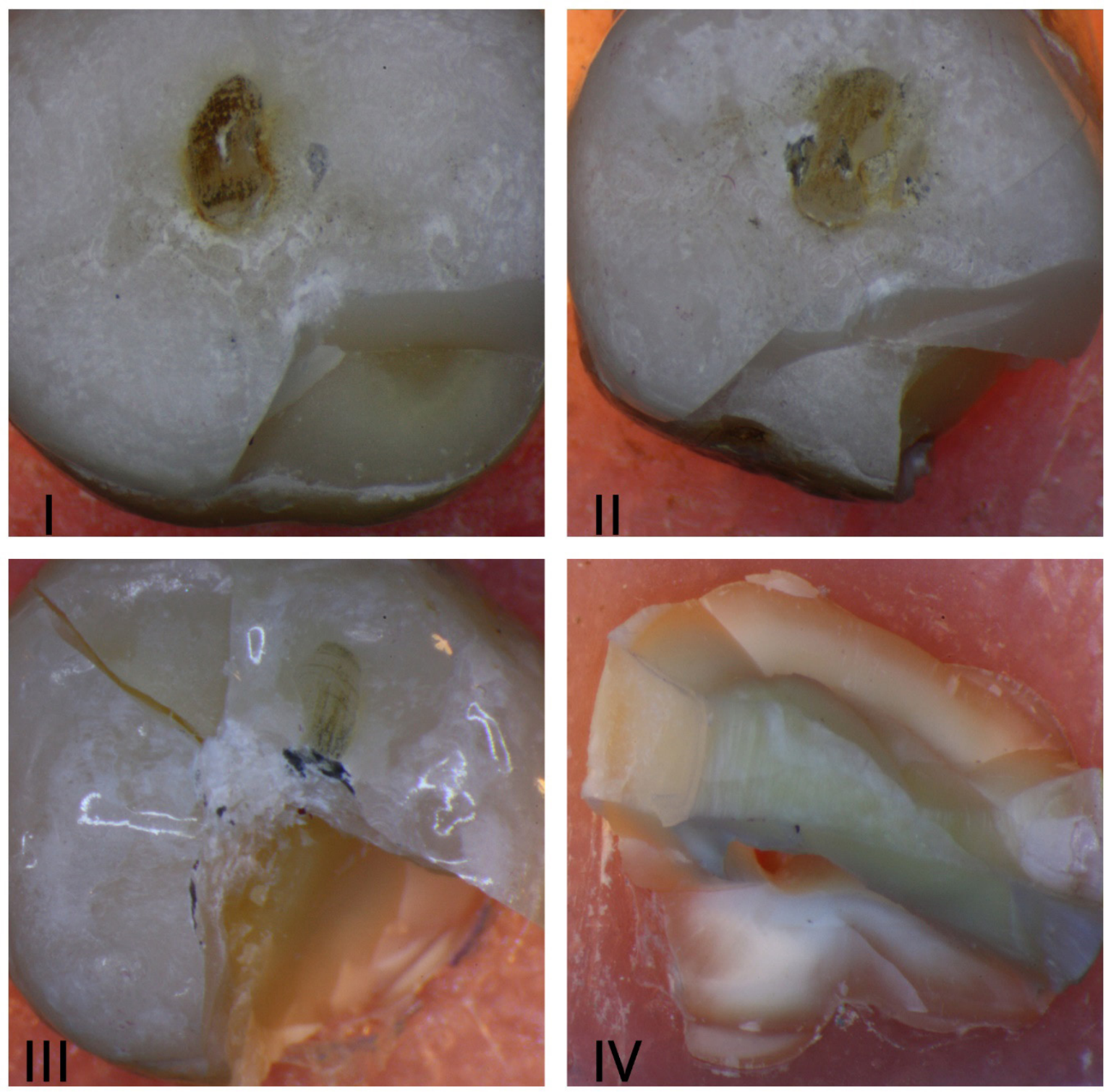

Figure 6: Failed specimens from occlusal view showing the failure mode

\section{STATISTICAL ANALYSIS}

IBM SPSS Statistics 22 (IBM SPSS, Turkey) program was used for statistical analysis of the findings of the present study. For analysis of the study data, the parameters were evaluated with the Shapiro Wilks test and the parameters were determined to be suitable for normal distribution. Two-way ANOVA test was used for the intergroup comparisons of parameters and comparison of quantitative data. In addition, one-way Anova test, Tukey HSD test and Student $t$ test were also used for intergroup analysis. Fisher Freeman Halton test was used to compare qualitative data. Significance was assessed at $\mathrm{p}<0.05$.

\section{RESULTS}

As shown in Tables 2 and 3, a statistically significant difference was found between the fracture force averages according to the groups $(\mathrm{P}<0.01)$. Mean fracture force of the control group was significantly higher than that of the LDC overlay $(p=0.001)$, LDC occlusal veneer 
$(\mathrm{p}=0.004)$, PIC overlay $(\mathrm{P}=0.007)$ and PIC occlusal veneer $(P=0.039)(p<0.01 ; p<0.05)$. No statistically significant differences were found among the fracture force averages of the LDC overlay, LDC occlusal veneer, PIC overlay and PIC occlusal veneer groups $(\mathrm{P}>0.05)$ (Table 2,3).

No statistically significant differences were found among the failure mode distributions of different ceramic materials $(\mathrm{P}>0.05)$ (Table 4). Table 4 indicates that more mode I and II fractures were found with occlusal veneers than with overlays, while more of mode IV fractures were found with PIC restorations than with LDC restorations, however; the difference between failure mode distributions according to the Burke Classification ${ }^{18}$ was not found to be statistically significant.

\section{DISCUSSION}

This study aimed to compare the fracture resistance and failure modes of two different CAD-CAM materials (LDC, PIC) in two different restorations (overlay, occlusal veneer) including one novel material and restoration (PIC, occlusal veneers) with natural teeth as controls. According to the findings of the current study, all materials and restorations tested could be used in the posterior region. However, no group was found as durable as natural teeth. Therefore, the null hypotheses were rejected.

The fracture resistance of restorative materials can be tested by using standard bars or plates or clinically realistic specimens. Standard test materials cannot simulate the modulus of elasticity and bonding

Table 2: Fracture force values of groups in Newtons, means, standard deviations (SD) (n=12).

\begin{tabular}{|c|c|c|}
\hline Groups & Mean \pm SD & $\mathbf{p}$ \\
\hline LDC Overlay & $1960,16 \pm 438,85$ & \multirow{5}{*}{$0,001 * *$} \\
\hline $\begin{array}{l}\text { LDC } \\
\text { Occlusal Veneer }\end{array}$ & $2148,53 \pm 460,18$ & \\
\hline PIC Overlay & $2196,77 \pm 427,84$ & \\
\hline $\begin{array}{l}\text { PIC } \\
\text { Occlusal Veneer }\end{array}$ & $2326,19 \pm 469,07$ & \\
\hline Control & $2942,3 \pm 724,60$ & \\
\hline
\end{tabular}

Table 3: Fracture force values according to material and the restoration in Newtons, means, standard deviations (SD).

\begin{tabular}{llc}
\hline \multicolumn{1}{l}{ Mean \pm SD } & p \\
\hline Material & $2054,34 \pm 450,16$ & $\mathbf{0 , 1 1 5}$ \\
\hline LDC & $2261,48 \pm 444,01$ & \\
\hline PIC & $2078,46 \pm 440,75$ & $\mathbf{0 , 2 3 0}$ \\
\hline Restoration & $2237,36 \pm 463,41$ & \\
\hline Overlay & & \\
\hline Student $t$ Test & &
\end{tabular}

Table 4: Descriptive statistics of failure mode (\%).

\begin{tabular}{|c|c|c|c|c|c|}
\hline & \multicolumn{4}{|l|}{ Failure Mode } & \multirow{3}{*}{$\mathbf{p}$} \\
\hline & $\begin{array}{l}\text { Restoration } \\
\text { fracture (I) }\end{array}$ & $\begin{array}{l}\text { Restoration } \\
\text { fracture including } \\
\text { a small tooth tissue } \\
\text { (II) }\end{array}$ & $\begin{array}{l}\text { Fracture including more } \\
\text { than half of the tooth and } \\
\text { not including periodontal } \\
\text { tissues (III) }\end{array}$ & $\begin{array}{l}\text { Restoration and/or tooth } \\
\text { fractures that included } \\
\text { periodontal tissues } \\
\text { (catastrophic fracture) } \\
\text { (IV) }\end{array}$ & \\
\hline & n (\%) & n (\%) & n (\%) & n (\%) & \\
\hline \multicolumn{6}{|l|}{ LDC } \\
\hline Overlay & $4(\% 33,3)$ & $2(\% 16,7)$ & $2(\% 16,7)$ & $4(\% 33,3)$ & \multirow{2}{*}{0,179} \\
\hline Occlusal Veneer & $6(\% 50)$ & $5(\% 41,7)$ & $0(\% 0)$ & $1(\% 8,3)$ & \\
\hline \multicolumn{6}{|l|}{ PIC } \\
\hline Overlay & $2(\% 16,7)$ & $5(\% 41,7)$ & $2(\% 16,7)$ & $3(\% 25)$ & \multirow{2}{*}{$\mathbf{0 , 5 3 0}$} \\
\hline Occlusal Veneer & $4(\% 33,3)$ & $4(\% 33,3)$ & $0(\% 0)$ & $4(\% 33,3)$ & \\
\hline
\end{tabular}

Fisher Freeman Halton Test 
characteristics of natural teeth. Therefore, to simulate oral conditions as much as possible, it is beneficial to use natural teeth as test specimens, as in the present study, where an effort was made to select teeth with similar dimensions to maximize standardization. ${ }^{13,19,20,21,22}$

As stated in previous studies ${ }^{23,24,25}$ composite resins have an elastic modulus that is close to natural teeth. Therefore, the composite resins have similar elastic properties to natural teeth and absorbs more functional forces than glass-ceramics. According to the manufacturer's information, the PIC material contains a polymer network like composite resins and has properties almost identical to those of natural teeth. In the current study, the control group consisted of natural teeth. Despite the material properties of PIC and minimal invasive cavity preparation of occlusal veneers, the results of the current study showed that no restoration could be as durable as natural teeth.

Static loading to fracture is a widely used method of determining whether a material or type of restoration is suitable for clinical use. However, this method can only provide information about a static situation, whereas restorations encounter millions of dynamic cycles in the mouth during their lifetime. In order to test the effect of fatigue and to simulate the conditions of the oral cavity, the specimens were subjected to artificial aging by applying thermal-dynamic loading with a chewing simulator. ${ }^{3,5,8,12,15,26}$ All ceramic restorations can be subjected to fatigue testing from 10,000 to $1,200,000$ cycles. $^{26}$ In the present study 100,000 dynamic and 5,000 thermal cycles were applied to the specimens for fatiguing. Subsequently, the specimens were subjected to static loading to failure as in previous studies. ${ }^{5,8,12,27}$

The high standard deviations obtained in the present study could be related to natural variations in tooth anatomy, possible defects that occur during preparation, cementation or any stage of study. However, these factors can also occur in clinical situations. The high range of fracture force values could therefore be interpreted as a natural performance of the groups. ${ }^{2}$

In the present study, no statistically significant differences were found in terms of fracture strength between the occlusal veneer and overlay groups ( $P$ $>0.01)$. However, the failures of the occlusal veneer groups were mostly within the restorative materials or included a small portion of enamel (79\% Mode I and II failures), whereas the overlay groups showed 54\% mode I and II failures. This means that, minimal invasive occlusal veneer restorations fractured with minimal damage to tooth structures. Other in vitro studies have reported that most failures of ultrathin composite or ceramic occlusal veneers exhibited cracks or fractures just within the restorative material. ${ }^{5,13,20,28}$ These results are consistent with the failure modes of occlusal veneers tested in the present study. Fractures limited to the restorative material or including just a small portion of enamel do not limit the longevity of the tooth because the restoration can be changed easily. However, failures that occur with extensive tooth substance loss may lead to endodontic treatment or even extraction of the tooth. ${ }^{2}$ Similar observations were reported by Guess et $\mathrm{al}^{11}$ who tested different types of restorations in terms of fracture resistance. Findings of this study showed mainly mode I and II fractures in minimal invasive preparations, whereas more extensive preparations showed mainly mode III and IV fractures. ${ }^{11}$

The results of the current study were not entirely consistent with those of a laboratory study that tested different dentin sealing procedures when teeth were restored with LDC occlusal veneers. ${ }^{8}$ The fractures were mostly catastrophic and involved the underlying tooth structure or the tooth structure in addition to the root (Mode III and IV fractures). The authors believe that these results were related to the dentin tissue they used as bonding substrate. In the present study, dentin was also used as the substrate tissue, but specimens of different morphology were used, the preparation, cementation and artificial aging methods differed.

According to the results of the current study, $29.1 \%$ of the PIC restorations and $20.8 \%$ of the LDC restorations exhibited mode IV catastrophic failures, with no statistically significant difference between materials in terms of failure mode. The higher ratio of catastrophic failures of PIC restorations may be a result of the high load absorption capacity of the material as claimed by the manufacturer, but such a conclusion may be premature. In a similar study, ${ }^{5}$ in the test group that was thermodynamically loaded, PIC and LDC restorations recorded the same ratio of mode IV catastrophic failures $(35 \%)$.

The fracture resistance of occlusal veneers made from different materials has been studied. Al-Akhali et al. $^{5}$ evaluated the fracture resistance of LDC, PIC, zirconia-reinforced ceramic and polymethylmethacrylate occlusal veneers with and without thermomechanical loading. Thermomechanical loading increased the fracture resistance of CAD-CAM zirconia-reinforced ceramic (Vita Suprinity), PIC (Vita Enamic) and polymethylmethacrylate (Telio CAD) occlusal veneers. 
LDC and zirconia-reinforced lithium disilicate occlusal veneers recorded significantly higher fracture resistance than the other groups. These results are not consistent with the current study, explained perhaps by a different number of thermomechanical loading cycles or other methodological differences.

Another study ${ }^{2}$ compared the fracture strength of occlusal veneers made of CAD-CAM resin nanoceramic (3M Lava Ultimate), PIC (Vita Enamic) and composite resin (Paradigm MZ100) materials with a static loading test after adhesive cementation of the restorations. According to the results, resin nanoceramic occlusal veneers showed significantly higher fracture strength $(2415 \pm 640 \mathrm{~N})$ than the other two materials (PIC 1727 $\pm 721 \mathrm{~N}$; composite $1752 \pm 576 \mathrm{~N})$. The occlusal veneer restorations had a central fossa of $0.3 \mathrm{~mm}$ in thickness, and the specimens were not subjected to thermomechanical aging. As has been shown, ${ }^{5}$ artificial aging can increase fracture resistance. Static loading tests without artificial aging and thinner restorative material thickness could explain the lower fracture strength values of the PIC occlusal veneers tested in this study.

Johnson et al. ${ }^{20}$ measured the fracture strength of CAD-CAM composite resin (Paradigm MZ100) and resin nanoceramic (3M Lava Ultimate) occlusal veneers. Their results showed that resin nanoceramic blocks, which have a similar chemical composition to PIC, recorded significantly higher fracture strength values than those of composite resin blocks. According to the present study, although there were no statistically significant differences, PIC restorations also had higher fracture force values $(2261.48 \pm 444.01 \mathrm{~N})$ than $\mathrm{LDC}$ restorations $(2054.34 \pm 450.16 \mathrm{~N})$.

Clausen et al. ${ }^{16}$ evaluated the effect of the cavity finishing line of occlusal restorations on fracture resistance and reported no effect on fracture resistance, implying the finish line could depend on the clinician's choice. In the present study, a non-retentive, straightforward preparation was chosen for the occlusal veneer group. Similar straightforward occlusal veneer preparations have been used in previous studies. In the overlay group, a traditional and widely usable overlay cavity design was chosen, and preparation guidelines were based on a previous study. ${ }^{14}$

The results of this study may lead to changes in clinical procedures. For patients with severely worn dentition, ultrathin occlusal veneer restorations made from CAD-CAM LDC or PIC materials can be successful alternatives to traditional complete-coverage restorations and overlays. Although there was no statistically significant difference, occlusal veneer restorations showed higher fracture values $(2237.36 \pm 463.41 \mathrm{~N})$ than overlay restorations $(2078,46 \pm 440.75 \mathrm{~N})$. In a recent study, ${ }^{3}$ the load bearing capacity of occlusal veneer and conventional crown restorations made from different materials was compared. According to this study's results that consistent with the current study, ultrathin occlusal veneers made from ceramic and hybrid ceramic materials could be used to restore worn teeth instead of conventional crowns. Furthermore; Ioannidis et al. ${ }^{3}$ reported that maximum masticatory forces can range from 200 to $800 \mathrm{~N}$ in the posterior region. In this study ${ }^{3}$ and in the present investigation, catastrophic failures occurred at about $2000 \mathrm{~N}$, static forces that are rarely expected in clinical practice.

There were limitations for the current study. At first, we have obtained fractures under static forces in vertical direction whereas clinical forces are the dynamic forces. In addition; although natural teeth are the realistic specimen materials for simulating clinical conditions it is not possible to obtain standard specimen dimensions and features with natural teeth.

\section{CONCLUSIONS}

Within the limitations of the current study the following conclusions can be drawn:

1) The outcomes of this study support the restorative treatment of severely worn teeth with minimal invasive occlusal veneers made of LDC and PIC CAD-CAM blocks to replace conventional restorations.

2) The novel PIC blocks were as resistant as LDC, but PIC restorations tended to have more catastrophic fractures, although there was no statistically significant difference. This conclusion needs to be supported by more studies.

3) Despite the goals of minimal invasive approaches, adhesive technologies and novel CAD-CAM materials, no combination of restoration and restorative material used in the current study was as durable as unrestored natural teeth.

\section{ACKNOWLEDGMENTS}

The authors have no conflicts of interest related to this study. This study was supported by Istanbul University Scientific Research Projects (Project number: 45949). 


\section{REFERENCES}

1. Magne P, Cheung R: Numeric simulation of occlusal interferences in molars restored with ultrathin occlusal veneers. J Prosthet Dent 2017;117:132137.

2. Egbert JS, Johnson AC, Tantbirojn D, et al: Fracture strength of ultrathin occlusal veneer restorations made from $\mathrm{CAD} / \mathrm{CAM}$ composite or hybrid ceramic materials. Oral Sci Int 2015;12:53-58.

3. Ioannidis A, Mühlemann S, Özcan M, et al. Ultra-thin occlusal veneers bonded to enamel and made of ceramic or hybrid materials exhibit loadbearing capacities not different from conventional restorations. J Mech Behav Biomed Mater 2019;90:433-440.

4. Mainjot AKJ: The One step-No prep technique: A straightforward and minimally invasive approach for full-mouth rehabilitation of worn dentition using polymer-infiltrated ceramic network (PICN) CADCAM prostheses. J Esthet Restor Dent 2018:1-9.

5. Al-Akhali M, Chaar MS, Elsayed A, et al: Fracture resistance of ceramic and polymer-based occlusal veneer restorations. Mech Behav Biomed Mater 2017;74:245-250.

6. Paulo J, Tribst M: Influence of ceramic material, thickness of restoration and cement layer on stress distribution of occlusal veneers. Dent Mater 2018:110.

7. Schlichting $\mathrm{LH}$, Resende $\mathrm{TH}$, Reis KR, et al: Simplified treatment of severe dental erosion with ultrathin CAD-CAM composite occlusal veneers and anterior bilaminar veneers. J Prosthet Dent 2016;116:474-482.

8. Yazigi C, Schneider H, Chaar MS, et al: Effects of artificial aging and progression of cracks on thin occlusal veneers using SD-OCT. J Mech Behav Biomed Mater 2018;88:231-237.

9. Bühler-Zemp P, Thomas Völke: IPS e.max CAD Scientific Documentation 2005:1-16.

10. Mclaren ED, Puri S. CEREC Materials Overview 2013:1-3.

11. Guess PC, Schultheis S, Wolkewitz M, et al: Influence of preparation design and ceramic thicknesses on fracture resistance and failure modes of premolar partial coverage restorations. J Prosthet Dent 2013;110:264-273.
12. Sasse M, Krummel A, Klosa K, et al:Influence of restoration thickness and dental bonding surface on the fracture resistance of full-coverage occlusal veneers made from lithium disilicate ceramic. Dent Mater 2015;31:907-915.

13. Schlichting LH, Maia HP, Baratieri LN, et al: Noveldesign ultra-thin $\mathrm{CAD} / \mathrm{CAM}$ composite resin and ceramic occlusal veneers for the treatment of severe dental erosion. J Prosthet Dent 2011;105:217-226.

14. Guess PC, Vagkopoulou T, Zhang Y, et al: Marginal and internal fit of heat pressed versus CAD/CAM fabricated all-ceramic onlays after exposure to thermo-mechanical fatigue. J Dent 2014;42:199209.

15. Yang R, Arola D, Han Z, et al: A comparison of the fracture resistance of three machinable ceramics after thermal and mechanical fatigue. J Prosthet Dent 2014;112:878-885.

16. Clausen JO, Abou TM, Kern M, et al: Dynamic fatigue and fracture resistance of non-retentive allceramic full-coverage molar restorations. Influence of ceramic material and preparation design. Dent Mater 2010;26:533-538.

17. Plotino G, Buono L, Grande NM, et al: Fracture resistance of endodontically treated molars restored with extensive composite resin restorations. J Prosthet Dent 2008;99:225-232.

18. C1322-05a A Standard practice for fractography and characterization of fracture origins in advanced ceramics ASTM International, West Conshohoken, PA (2005).

19. Skouridou N, Pollington S, Rosentritt M, et al: Fracture strength of minimally prepared all-ceramic CEREC crowns after simulating 5 years of service. Dent Mater 2013;29:70-77.

20. Johnson AC, Versluis A, Tantbirojn D, et al: Fracture strength of CAD/CAM composite and composite-ceramic occlusal veneers. J Prosthodont Res 2014;58:107-114.

21. Magne P, Schlichting LH, Maia HP, et al: In vitro fatigue resistance of $\mathrm{CAD} / \mathrm{CAM}$ composite resin and ceramic posterior occlusal veneers. J Prosthet Dent 2010;104:149-157.

22. Magne P, Carvalho AO, Bruzi G, et al: Fatigue resistance of ultrathin $\mathrm{CAD} / \mathrm{CAM}$ complete crowns with a simplified cementation process. J Prosthet Dent 2015;114:574-579. 
23. Carvalho AO, Bruzi G, Giannini $\mathrm{M}$, et al: Fatigue resistance of $\mathrm{CAD} / \mathrm{CAM}$ complete crowns with a simplified cementation process. J Prosthet Dent 2014; $111: 310-317$.

24. Fonseca RB, Fernandes-Neto AJ, Correr-Sobrinho $\mathrm{L}$, et al: The influence of cavity preparation design on fracture strength and mode of fracture of laboratory-processed composite resin restorations. J Prosthet Dent 2007;98:277-284.

25. Soares PV, Santos-Filho PCF, Gomide HA, et al: Influence of restorative technique on the biomechanical behavior of endodontically treated maxillary premolars. Part II: Strain measurement and stress distribution. J Prosthet Dent 2008;99:114122.
26. AbouBakr Mohamed K, Salah El Dean El Mahallawi O, Abd El Latif Zaki A : In-vitro Fatigue Resistance of Bonded Posterior Occlusal Veneers: A Systematic Review. Indian J Sci Technol 2016;9-34.

27. Attia A, Kern M: Influence of cyclic loading and luting agents on the fracture load of two all-ceramic crown systems. J Prosthet Dent 2004;92:551-556.

28. Magne P, Stanley K, Schlichting LH: Modeling of ultrathin occlusal veneers. Dent Mater 2012;28:777782. 